\title{
THE EFFECTIVENESS OF ARIAS LEARNING MODEL ASSISTED AUDIOVISUAL MEDIA IMPROVING LEARNING OUTCOMES
}

\author{
Nur Laila Molla \\ Department of English, Universitas Pancasakti Tegal, Indonesia \\ E-mail: mollacourse@gmail.com \\ Muhammad Arif Budiman Sucipto \\ Guidance and Counseling Department, Universitas Pancasakti Tegal, Indonesia \\ E-mail: arifups88@gmail.com
}

\begin{abstract}
APA Citation: Molla, N. L., \& Sucipto, M. A. B. (2019). The effectiveness of ARIAS learning model assisted audiovisual media improving learning outcomes. Indonesian Journal of Learning and Instruction, 2(1), 53-64. doi: 10.25134/ijli.v2i01.1684.
\end{abstract}

Received: 19-12-2018

Accepted: 19-02-2019

Published: 01-04-2019

Abstract: ARIAS learning model instills confidence, relevance, interest, attention, and evaluation to find out success and pride in the results of achievement. With the help of audiovisual media, it will further enhance students' interest, attention, and activeness. Research Objectives 1) finding out differences in learning outcomes of significant ARIAS learning model with audiovisual media and conventional learning models. 2) Determining effectiveness of using ARIAS Learning Model assisted by audiovisual assisted audiovisual media in improving learning outcomes with conventional learning models. Quantitative research is a true design experiment. Design used was a pretest-posttest control group design. The population is all the third-semester students majoring in economics. Sample by means of non probability sampling with a purposive sampling technique, Data analysis techniques use independent test t-test and paired test. Results of independent test test obtained $\mathrm{t}$ count $=3.375$ with sig $(2$ tailed $)=0.001<0.05$ which means a significant difference in learning outcomes between ARIAS learning model with conventional learning models. Paired test results obtained a value of $t$ count of $-20,378$ with the sig. (2tailed) $=0.00<0.05$ which means an increase in learning outcomes between ARIAS learning models with conventional models. The results obtain of average pre-test is 56.07 and post-test is 79.97. Furthermore, the conclusion is Arias assisted audiovisual learning model effectively improved learning outcomes of English subjects.

Keywords: ARIAS learning model; audiovisual; college student; learning outcomes; media.

\section{INTRODUCTION}

Education is the key to the progress of a nation or nation. According to (Zein, 2017) said that Indonesia is ranked second after China in terms of the number of students learning English as a foreign language with numbers currently reaching more than 26 million. This is because education also influences the way of thinking so that in the end it becomes a component to build a nation's civilization.

The development of English education in Indonesia, and shows that it has been undergoing a great transformation in recent years. Entering the new millennium, there was another resurgence of interest in English within Indonesian society. Parents in many parts of the country were aware that the 
increasingly globalized world meant that strong preparation in English education would be vital in the coming years. Furthermore, parents also believed in the importance of English education at the University especially for Economics students at Pancasakti University Tegal. In a country generally, education is regulated in a law. In the legal system in Indonesia, national education is regulated in the Republic of Indonesia Law Number 2 of 1989 which was later renewed by the Law of the Republic of Indonesia Number 20 of 2003 concerning the national education system stipulates that the goal of national education is to educate the life of the nation and develop Indonesian people as a whole, namely humanity who have faith and devotion to God Almighty and noble character, possess knowledge and skills, physical and spiritual health. a solid and independent personality and a sense of community and national responsibility.

In the context of the 22nd century, education should play a role in forming a complete human being so that Indonesia becomes a responsible development implementer. Development executives are also responsible for forming Indonesians who are able to play a role in the 22 nd century and through the education sector can improve the quality in accordance with national development needs, namely human beings who have creative and innovative souls, people who have far-sighted insights and attitudes independent. This is in accordance with the function of national education, namely to develop capabilities, improve the quality of life and human dignity of Indonesia in order to realize national goals.

In the education system in Indonesia, the government or executive, in this case, the Ministry of Education and Culture makes the education system in stages so that the implementation of the education process can take place systematically and sustainably. The government in implementing the National Education System Law has made the curriculum then embodied in the form of Syllabus and Learning Program Plans (RPP).
The curriculum chosen at this university is that Curriculum is based on KKNI which should be oriented towards student learning centers (Hidayat \& Waseso, 2017) and (Setiawan, 2017). The material in a learning process needs to be presented to students in a form that will help to learn. this presentation will involve using according to Nation and Macalister techniques and procedures (National \& Macalister, 2010).

At the end of each learning process, an evaluation is carried out in the form of tests with various formats to measure the level of success and the level of absorption of students on learning material. Materials can be informative (informing the learner about the target language), instructional (guiding the learner in practicing the language), experiential (providing the learner with experience of the language in use), eliciting (encouraging the learner to use the language) and exploratory (helping the learner to make discoveries about the language). Improvements or changes in curriculum continue to be carried out by the government for adjustments to the development of the times and challenges that continue to evolve according to circumstances. This change is also carried out to anticipate the conditions in the future, so that material is included in the anticipatory learning material. The education process will eventually be evaluated in the form of learning outcomes. Evaluation Educational experts have a variety of opinions. From various opinions, it was concluded that learning outcomes are a skill that someone receives after participating in learning activities. learning outcomes can certainly be observed in various models, cognitive, affective and psychomotor. that learning outcomes can be associated with the occurrence of a change in a person's behavior in tendencies with skills in the development process that occur after the learning process by giving certain treatments and exercises (Dimyati \& Mudjiono, 2013). Meanwhile, there is explanation that learning outcomes are changes in behavior in accordance with the objectives stated in the curriculum. 
Furthermore, applying the definition of measurement is the application of measuring instruments to certain objects. Measurement results can be in the form of numbers, symbols or can also be decryption about the status of the object being measured. Another opinion gives an understanding that measurement is a process of giving numbers to something or someone based on certain rules. Another explanation of attitudes toward language, which is an attitude that is a necessary condition in the language learning process. Attitude is behavior that is shown in facing or accepting something; in the language teaching and learning process, there are positive and negative attitudes of students to speech / second language / foreign languages. This positive attitude can facilitate the learning process of the second language.

A person's attitude when used in English teaching and learning activities, The attitude of someone when used in teaching and learning activities in English, there will be individuals who like learning English (positive attitude) or who behave otherwise that is not like learning English (negative attitude). For students who have a positive attitude about English will learn with their own volition and devote their full attention to English subject matter. According to Sutiah (2011) , it was stated that English language learning refers to some means that students have positive perceptions of communication using English. The opposite of students' negative attitudes about learning English will lead to inactivity of students in their learning activities and ultimately will negatively affect the English lessons they learn. Or in other words, a student who has a positive attitude towards learning English will love the English lesson as well, so that students will really learn. So what is meant by student attitudes in this qualification paper is the positive tendency of students to respond to English subjects or negative tendencies in responding to English subjects.
English is very important at this time, in the era of globalization there are many developments in all fields. For example in the fields of technology, trade, business, economics, etc. Because of the importance of the role of English as an international communication tool between nations, so English is taught at various levels of education in Indonesia. This language is taught from the lowest level to the college level. From the above conditions, the English language is very necessary to be taught to college students. Students really need to be equipped with English.

According to Weiguo, the direct relationship between English and English economic has highlighted the practical value or commercial potential of English, People who are now interested in English for various reasons. As studying abroad has become popular for gaining moderate knowledge and achieving personal success.

English is very important at this time, in the era of globalization there are many developments in all fields. For example in the fields of technology, trade, business, economics, etc. Because of the importance of the role of English as an international communication tool between nations, so English is taught at various levels of education in Indonesia. This language is taught from the lowest level to the college level. From the above conditions, the English language is very necessary to be taught to college students. Students really need to be equipped with English. According to $\mathrm{Qu}$ (2012) the direct relationship between English and English economic has highlighted the practical value or commercial potential of English, People who are now interested in English for various reasons. As studying abroad has become popular for gaining moderate knowledge and achieving personal success.

According to Bolton (2008) stated that based on the results of the Indonesian country's English survey only 5\% of the population using English is estimated to be 
around 12 billion. It can be concluded that the Indonesian state is still lagging behind other Asian countries such as India and the Philippines, where the majority of the population uses English. Students majoring in economics in English language subjects still consider English language courses to be difficult subjects. Many factors that influence student learning outcomes include internal (Pertiwi, Sudarsono, \& Arifin, 2015) in line with (Ahmadi \& Supriyono, 2013) stating that there are several factors that influence learning outcomes to include internal and external factors. One of the things that happened was because many students did not understand the delivery of material provided by the lecturers. So that many students are looking for their own activity by chatting, disturbing other friends and so on.

Besides that, the lecturers are not very deep in the characteristics of students who are more focused on teaching in order to achieve learning goals. Learning systems that are only guided by modules make students' understanding abilities have not met the criteria of completeness and can lead to underdevelopment in learning. Based on the results of observations in the field, it shows that the learning outcomes of students with economic majors are less than optimal can be seen from the number of learning outcomes that meet the completeness level of 30\%.

One reason for the decline in learning outcomes is the use of learning models that are still conventional. With the continued growth of multimedia learning resources, it is important to offer methods to help students explore and obtain relevant learning information effectively (Gu \& Guo, 2017). If this is allowed continuously without a solution to the solution, it will be very detrimental to students where students cannot obtain maximum learning outcomes. for this reason, it is necessary to have the right learning model to overcome this problem.

Many learning models and strategies have been carried out to improve the quality of learning English courses. One model offered to be able to improve learning outcomes in English is using the ARIAS development model from the ARCS model (Carson, 2006). ARIAS model is an acronym of Assurance, Relevance, Interest, Assassment, And Satisfaction which is a modification of the ARCS acronym model of Attention, Relevance, Confidence, and Satisfaction) (Sulistyaningrum, Karyanto, \& Sunarno, 2015) .ARIAS learning model is a learning model that instills confidence, relates to daily life, arouses interest and attention, evaluates to find out successes and feels proud of the results achieved. Risha, Tarmizi, \& Saminan (2017) with the research title the application of an integrated ARIAS model shows the results of research on cyclical 1 completeness level of 58\%, cycle 2 of $67 \%$ and cycle 3 of $83 \%$ and can be categorized very well. In line with the results of Anugrah Lestari et al's research entitled The Effect of Arias Learning Model on Mathematics Learning Outcomes, the results of the study showed that the increase in control class learning outcomes was 76.90 while the control class was 65.32 . can be interpreted that there are differences in the average of the two classes. From the explanation of the results of the above research, the ARIAS learning method has been proven to improve learning outcomes.

According to Tomlinson (2012), the material for language learning will be regarded as anything that can be used to facilitate language learning, including textbooks, videos, readers of flash card-level web site games and cell phone interactions. In order for learning outcomes to be more maximal, the role of the media is also very much needed, one of the media who gets interested and attention in the learning process is audiovisual media. The basis for consideration of media selection must also be considered in accordance with media selection techniques (Budiman, 2018). The use of appropriate media can also overcome student passivity. According to Budiman (2017), audiovisual media is media that contains elements of image and sound. so the media used to help present learning material 
is media that has elements of motion pictures or video and sound elements that are combined in video form.

In general, the media has uses, among others, reducing verbalism, reducing space limitations, sensory power time, passivity and different experiences (Sadiman, Raharjo, Haryono, \& Rahardjito, 2012) With the presence of audiovisual or video media, it will help in student learning situations where the senses of the listener and the senses of vision can work optimally in receiving information in the form of knowledge of attitudes and new ideas that can improve learning outcomes.

The formulation of the problem in this study is 1) is there a significant difference in learning outcomes between ARIAS learning models assisted by audiovisual media with conventional learning models? 2) Is the ARIAS learning model with audiovisual media as effective in increasing results? the purpose of this study is 1) to find out is there a significant difference in learning outcomes between the ARIAS learning model with audiovisual media and conventional learning models. 2) to determine the effectiveness of the use of the ARIAS Learning Model assisted by audio-visual audio-assisted media in improving learning outcomes.

\section{METHOD}

This research method used a quantitative research approach, according to Sugiyono (2014) quantitative research is a research method based on something that really happened and experienced as reality, used to examine population and certain samples, the sample was conducted on a random, data collection with instruments, analysis was quantitative and aimed at testing the hypothesis. The type of research used in this study is experimental research. Experimental research is research that is used to look for influences on something else under controlled conditions there are 4 types of experimental design that can be used namely pre-experimental design, true experimental design, Factorial design and quasiexperimental. In this study researchers used the True Experimental design research design in other words pure research wherein in this study the researchers controlled all external variables which would influence the experimental group (Sugiono, 2010). To anticipate leaks and control variables from the outside, the researcher ensures that no student who follows tutoring outside the lecture behaves honestly and does not provide information about the process of lectures.

The design chosen in this study was a pretest-posttest control group design. In this design, there are 2 groups, namely the experimental group and the control group where each group is randomly selected then given a pretest to find out the initial condition is there a difference or not in the initial condition before the treatment is carried out. The population in this study were students of the Pancasakti University Faculty of Economics, the third-semester accounting department, amounting to 89 students. In this study, the researcher took the sample by means of non probability sampling with a purposive sampling technique.

In determining the sample based on certain characteristics with consideration, namely the value of the results of the midterm exam (UTS) English courses. Before carrying out to the parametric test phase, the most compulsory requirement is to conduct an analysis prerequisite test in the form of a test for normality and homogeneity. Normality Test of Middle Semester Exams Based on the above output shows the significance value ( $\mathrm{sig}$ ) of the classes of accreditation $\mathrm{A}, \mathrm{B}$, and $\mathrm{C}$ each class exceeds $>0.05$, it can be concluded that the three classes are normally distributed so that it can be used in parametric statistical tests. Based on the homogeneity test results obtained a significance value of 0.922 . Basic decision making if the significance value is> 0.05 , the data distribution is homogeneous 
but if the significance value is $<0.05$, the data distribution is not homogeneous.

This means that the value of the midterm exam results in English classes A, B and $\mathrm{C}$ in Accounting has a homogeneous variance. More complete data can be seen in the attachment. The similarity test results on the average of two sample groups before being given treatment need to be tested using the similarity test of two averages. In the table above shows the calculation results of class A and B Basic decision making if the value is a sig. (2-tailed) $<0.05$, there are significant differences between class $\mathrm{A}$ and B. Whereas if the value is a sig. (2-tailed)> 0.05 then there was no significant difference between the class A and class B samples. Based on the table above, please use the sig. (2-tailed) 0899 which means there is no significant difference in the mean scores for the midterm examination results between Class A and Class B.

Based on decision making, class $\mathrm{A}$ is chosen as the experimental class and class B as the control class. The number of class A students is 30 and the number of class B is 29. To be able to control the dependent variable and the independent variable it is necessary to control variables as controllers so that the research is not far from the problem for which the variables constrained and made equal are facilities, sources, media and checking the involvement of students in tutoring.

Data collection techniques used in this study tested techniques, observation, and documentation techniques. Data measurement tools on test instruments or questionnaires using test item validity, instructional reliability, level of difficulty and power difference questions. The data analysis technique used is 2 stages, namely the initial stage consisting of a normality test, homogeneity test, and equality test. The final stage is the normality test, homogeneity test, independent test sample test and improvement in learning outcomes test.

\section{RESULTS AND DISCUSSION}

The test instrument tryout was carried out first before being given to the experimental group and the control group. The tryout was carried out on other respondents who were not part of the sample. The purpose of carrying out this tryout was to obtain cognitive learning outcomes in learning English. The tryout was carried out by researchers, namely in the tax department of the economics faculty of Pancasakti University, with 30 questions and respondents totaling 30 students. The results of the study $r$ count then compared with $r$ table with the number of respondents 30 students, namely $\mathrm{N}=30$ with a significance level of $5 \%$ is 0.361 . Of the 30 questions, the value of $r$ was calculated from 0.44 to 0.66 .

Thus, it can be criticized that the 30 questions are valid. After carrying out the validity test, the next test prerequisite was to test the reliability of the instrument which is useful to determine the level of accuracy, accuracy or accuracy of an instrument. In this study used the spearman-brown formula. From the calculation results obtained by the value of $\mathrm{r} 11$ of 0.90 then consulted on $\mathrm{r}$ table with $\mathrm{N}=30$ and a significance level of $5 \%$ is 0.361 . because $r$ count $>r$ table is $0.90>0.361$ then the 30 questions are declared reliable.

\section{Initial conditions}

The initial condition after being determined by class $\mathrm{A}$ as an experimental group of 30 students consisted of $\mathrm{x}$ male and $\mathrm{y}$ female and class $\mathrm{B}$ as the control group, amounting to 29 students consisting of $\mathrm{x}$ males and $\mathrm{y}$ females. The results of the pre-test experimental and control classes that had been done by students amounted to 30 multiple choice questions and the lecturer supervised and observed the way of the pretest.

Table 1. The results of the pre-test experimental and control classes 


\begin{tabular}{cccc}
\hline Total & 1680 & Total & 1653 \\
Average & 40 & Average & 43 \\
Variance & 90.20 & Variance & 94.79 \\
Elementary school & 9.50 & Elementary school & 9.74 \\
\hline
\end{tabular}

The data above shows the initial conditions of the experimental group and the control class whether departing from different initial conditions or the same. This was needed before doing treatment. This data was tested using parametric statistical data, it needed to be tested using normality and homogeneity tests.

Table 2. The results of the calculation of the pretest normality test in two classes

\begin{tabular}{ccccc}
\hline Group & Kolmogorov Smirnov & Df & sig & Criteria \\
\hline Experiment & 0.094 & 30 & 0.200 & Normal distribution \\
Control & 0.138 & 29 & 0.165 & Normal distribution \\
\hline
\end{tabular}

From the table above shows the results of the calculation of the pretest normality test in two classes obtained significance values for the experimental group as much as 0.200 and the control group at 0.165 and both classes both experimental and control classes more than 0.05 , it can be concluded that the data are normally distributed. Thus fulfilling the requirements for parametric statistical test techniques.

Table 3. Test the homogeneity of the initial condition data from the experimental and control groups

\begin{tabular}{cccccc}
\hline \multicolumn{7}{c}{ ANOVA } & & & \\
Student Learning Outcomes & & & & \\
Between Groups & Sum of Squares & df & Mean Square & F & Sig. \\
Within Groups & 12.845 & 1 & 12.845 & .139 & .711 \\
Total & 5269.867 & 57 & 92.454 & & \\
\hline
\end{tabular}

Based on the above calculation shows that the results of the pretest data using Levene test obtained sig $=0.711>0.05$, which means that the initial condition data from the experimental class and the control class have the same variant.

Table 4. The pretest data equality test results

\begin{tabular}{|c|c|c|c|c|c|c|c|c|c|c|}
\hline \multicolumn{11}{|c|}{ Independent Samples Test } \\
\hline & & \multicolumn{3}{|c|}{$\begin{array}{l}\text { Levene's Test for } \\
\text { Equality of Variances }\end{array}$} & \multicolumn{6}{|c|}{ t-test for Equality of Means } \\
\hline & & \multirow[t]{2}{*}{$\mathbf{F}$} & \multirow[t]{2}{*}{ Sig. } & \multirow[t]{2}{*}{$\mathbf{t}$} & \multirow[t]{2}{*}{ df } & \multirow[t]{2}{*}{$\begin{array}{l}\text { Sig. (2- } \\
\text { tailed) }\end{array}$} & \multirow{2}{*}{$\begin{array}{l}\text { Mean } \\
\text { Differen } \\
\text { ce }\end{array}$} & \multirow{2}{*}{$\begin{array}{c}\text { Std. } \\
\text { Error } \\
\text { Differen } \\
\text { ce }\end{array}$} & \multicolumn{2}{|c|}{$\begin{array}{l}\text { 95\% Confidence } \\
\text { Interval of the } \\
\text { Difference }\end{array}$} \\
\hline & & & & & & & & & Lower & Upper \\
\hline PreTest & $\begin{array}{c}\text { Equal } \\
\text { variances } \\
\text { assumed }\end{array}$ & .000 & .996 & .373 & 57 & .711 & -.933 & 2.504 & -5.947 & 4.081 \\
\hline $\begin{array}{l}\text { Learning } \\
\text { Results }\end{array}$ & $\begin{array}{c}\text { Equal } \\
\text { variances } \\
\text { not } \\
\text { assumed }\end{array}$ & & &.- & $\begin{array}{c}56.80 \\
1\end{array}$ & .711 & -.933 & 2.505 & -5.950 & 4.083 \\
\hline
\end{tabular}

Based on the calculation of the value of $\mathrm{t}$ count $=-0.373$ with sig $=0.933>0.05$ which means that there is no significant difference from the results of the pretest 
between the experimental group and the disk group. It can be interpreted that the two groups originated from the same initial conditions, and can be continued by giving treatment to the experimental group with the arias learning model assisted by audio media and control groups with conventional learning models assisted by the media.

Table 5. Equivalency test results of pretest experimental class and control class

\begin{tabular}{|c|c|c|c|c|c|}
\hline \multicolumn{6}{|c|}{ Group Statistics } \\
\hline \multirow{3}{*}{$\begin{array}{l}\text { PreTest Learning } \\
\text { Results }\end{array}$} & Class & $\mathbf{N}$ & Mean & $\begin{array}{c}\text { Std. } \\
\text { Deviation }\end{array}$ & $\begin{array}{l}\text { Std. Error } \\
\text { Mean }\end{array}$ \\
\hline & $\begin{array}{l}\text { Class A Pretest } \\
\text { Exneriment }\end{array}$ & 30 & 56.07 & 9.497 & 1.734 \\
\hline & Class B Pretest Control & 29 & 57.00 & 9.736 & 1.808 \\
\hline
\end{tabular}

Table 6. Independent samples test

\begin{tabular}{|c|c|c|c|c|c|c|c|c|c|c|}
\hline \multirow{5}{*}{$\begin{array}{c}\text { PreTest } \\
\text { Learning } \\
\text { Results }\end{array}$} & & \multicolumn{2}{|c|}{$\begin{array}{l}\text { Levene's Test } \\
\text { for Equality } \\
\text { of Variances }\end{array}$} & \multicolumn{7}{|c|}{ t-test for Equality of Means } \\
\hline & & \multirow{2}{*}{$\mathbf{F}$} & \multirow{2}{*}{ Sig. } & \multirow{2}{*}{$\mathbf{t}$} & \multirow{2}{*}{ df } & \multirow{2}{*}{$\begin{array}{c}\text { Sig. } \\
(2- \\
\text { tailed } \\
\quad\end{array}$} & \multirow{2}{*}{$\begin{array}{c}\text { Mean } \\
\text { Differen } \\
\text { ce }\end{array}$} & \multirow{2}{*}{$\begin{array}{l}\text { Std. Error } \\
\text { Difference }\end{array}$} & \multicolumn{2}{|c|}{$\begin{array}{l}\text { 95\% Confidence Interval } \\
\text { of the Difference }\end{array}$} \\
\hline & & & & & & & & & Lower & Upper \\
\hline & $\begin{array}{c}\text { Equal } \\
\text { variances } \\
\text { assumed }\end{array}$ & .000 & .996 & $\begin{array}{c}- \\
.373\end{array}$ & 57 & .711 & -.933 & 2.504 & -5.947 & 4.081 \\
\hline & $\begin{array}{c}\text { Equal } \\
\text { variances not } \\
\text { assumed }\end{array}$ & & & $\begin{array}{c}- \\
.373\end{array}$ & $\begin{array}{r}56 \\
.8 \\
01 \\
\end{array}$ & .711 & -.933 & 2.505 & -5.950 & 4.083 \\
\hline
\end{tabular}

The results of the table show that the value of $t$ count is $-0.373 \mathrm{sig}$ (2tailed) 0.711 which corresponds to the formula sig. (2tailed) $>0.05$ and thus there is no significant difference between the results of the experimental class pre-test and the control class. So, the experimental class was treated using the ARIAS method assisted by Audio Visual media and control classes using conventional methods.

Table 7. Post-test results after being given treatment in the experimental group and the experimental class

\begin{tabular}{cccc}
\hline \multicolumn{1}{c}{ Experiment Class } & \multicolumn{2}{c}{ Control Class } \\
\hline Total & 2399 & Total & 2127 \\
Average & 79.97 & Average & 73.34 \\
Variance & 61.206 & Variance & 52.163 \\
Elementary school & 7.823 & Elementary school & 7.222 \\
\hline
\end{tabular}

Table 8. Data from post-test results from different power tests

\begin{tabular}{cccccc}
\hline Group & N & Mean & Variant & Sig. (2-tailed) & Criteria \\
\hline Experiment & 30 & 79.97 & 61.206 & 0.001 & There are \\
Control & 29 & 73.34 & 52.163 & 0.001 & differences \\
\hline
\end{tabular}

From the above data shows the average post-test results of the experimental group amounted to 79.97 and the control group at 73.34. And seen from the basis of decision making if the value of sig. (2-tailed) $<0.05$, then there are significant differences between the experimental class and the control class. Then it can be concluded based on the decision making the value of $\mathrm{t}$ count 3.375 sig. $\quad(2$-tailed) $=0.001<0.05$, there are significant differences between the experimental class and the control class. 
Table 9. Improved learning outcomes can be seen from the results of normalized gains

\begin{tabular}{cccccc}
\hline Gain & Criteria & \multicolumn{2}{c}{ Experimental class } & \multicolumn{2}{c}{ Control class } \\
\hline $0.7<\mathrm{g}$ & High & 4 & $13 \%$ & 0 & $0 \%$ \\
$0.3<\mathrm{g} \leq 0.7$ & Enough & 25 & $84 \%$ & 20 & $69 \%$ \\
$\mathrm{~g}<0.3$ & Low & 1 & $3 \%$ & 9 & $31 \%$ \\
Total & & 30 & $100 \%$ & 29 & $100 \%$ \\
\hline
\end{tabular}

From the table above shows an increase in the experimental class which is classified as high by $13 \%$, classified as quite an $84 \%$ while classified as low by $3 \%$. In the control class that is classified as high, there is none, classified as enough at $69 \%$ and classified as low at $31 \%$.

To test the increase in learning outcomes, it can be seen in the test table paired with the t-test.

Table 10. Results Test of difference in improvement in learning outcomes

\begin{tabular}{cccccc}
\hline & & Paired Samples Statistics & & \\
& & Mean & N & $\begin{array}{c}\text { Std. } \\
\text { Deviation }\end{array}$ & $\begin{array}{c}\text { Std. Error } \\
\text { Mean }\end{array}$ \\
\multirow{2}{*}{ Pair 1 } & Pre-test Experiment & 56.07 & 30 & 9.497 & 1.734 \\
\multirow{2}{*}{ Pair 2 } & Post-test Experiment & 79.97 & 30 & 7.823 & 1.428 \\
& Pre-test Control & 57.00 & 29 & 9.736 & 1.808 \\
& Post-test Control & 73.34 & 29 & 7.222 & 1.341 \\
\hline
\end{tabular}

Table 11. Paired samples test

\begin{tabular}{|c|c|c|c|c|c|c|c|c|c|}
\hline \multicolumn{10}{|c|}{ Paired Differences } \\
\hline & & \multirow[t]{2}{*}{ Mean } & \multirow{2}{*}{$\begin{array}{l}\text { Std. } \\
\text { Deviati } \\
\text { on }\end{array}$} & \multirow[t]{2}{*}{$\begin{array}{l}\text { Std. } \\
\text { Error } \\
\text { Mean }\end{array}$} & \multicolumn{2}{|c|}{$\begin{array}{l}\text { 95\% Confidence } \\
\text { Interval of the } \\
\text { Difference }\end{array}$} & \multirow[t]{2}{*}{$\mathbf{t}$} & \multirow[t]{2}{*}{ df } & \multirow[t]{2}{*}{$\begin{array}{l}\text { Sig. (2- } \\
\text { tailed) }\end{array}$} \\
\hline & & & & & Lower & Upper & & & \\
\hline Pair 1 & $\begin{array}{l}\text { Pre-test } \\
\text { Experiment - } \\
\text { Post-test } \\
\text { Experiment }\end{array}$ & $\begin{array}{c}- \\
23.90 \\
0\end{array}$ & 6.424 & 1.173 & -26.299 & -21.501 & -20.378 & 29 & .000 \\
\hline Pair 2 & $\begin{array}{l}\text { Pre-test } \\
\text { Control - Post- } \\
\text { test Control }\end{array}$ & $\begin{array}{c}- \\
16.34 \\
5\end{array}$ & 7.798 & 1.448 & -19.311 & -13.379 & -11.288 & 28 & .000 \\
\hline
\end{tabular}

The table showed the experimental class and class the sig. (2-tailed) value = $0.000<0.05$, which means that there is an increase in learning outcomes. To see how much influence can be seen from the paired sample t-test where the average value of the experimental class before being given treatment (pre-test) of 56.07 while after being given treatment (post-test) of 79.97 means that there is an increase in learning outcomes thus can It was concluded that the audiovisual aided learning model was effective in improving the learning outcomes of English subjects.
The results of this study indicated that the ARIAS learning model assisted by effective audiovisual media contributes in the form of increasing learning outcomes in English subjects. The initial conditions based on the results of the experimental class pretest and the control class are relatively the same, as evidenced by the results of the experimental and control class t-test based on the calculation of sig. (2-tailed) $=0.933>$ 0.05 , which means that there is no difference in real Hasil pre-test between experimental class and control class. After doing the treatment in the form of an audio-visual 
learning ARIAS model for the experimental class and conventional audio-assisted learning there are different learning outcomes. This is evident from the results of the experimental class t-test and control class based on the results of the calculation of sig. $(2$-tailed $)=0.001<0.05$, which means that there are significant differences. The ARIAS learning model can also effectively improve learning outcomes in a high category by $13 \%$, an adequate category of $84 \%$ and a low category of $3 \%$. Different conventional models of increase were achieved in a sufficient category of $69 \%$ and low by $31 \%$.

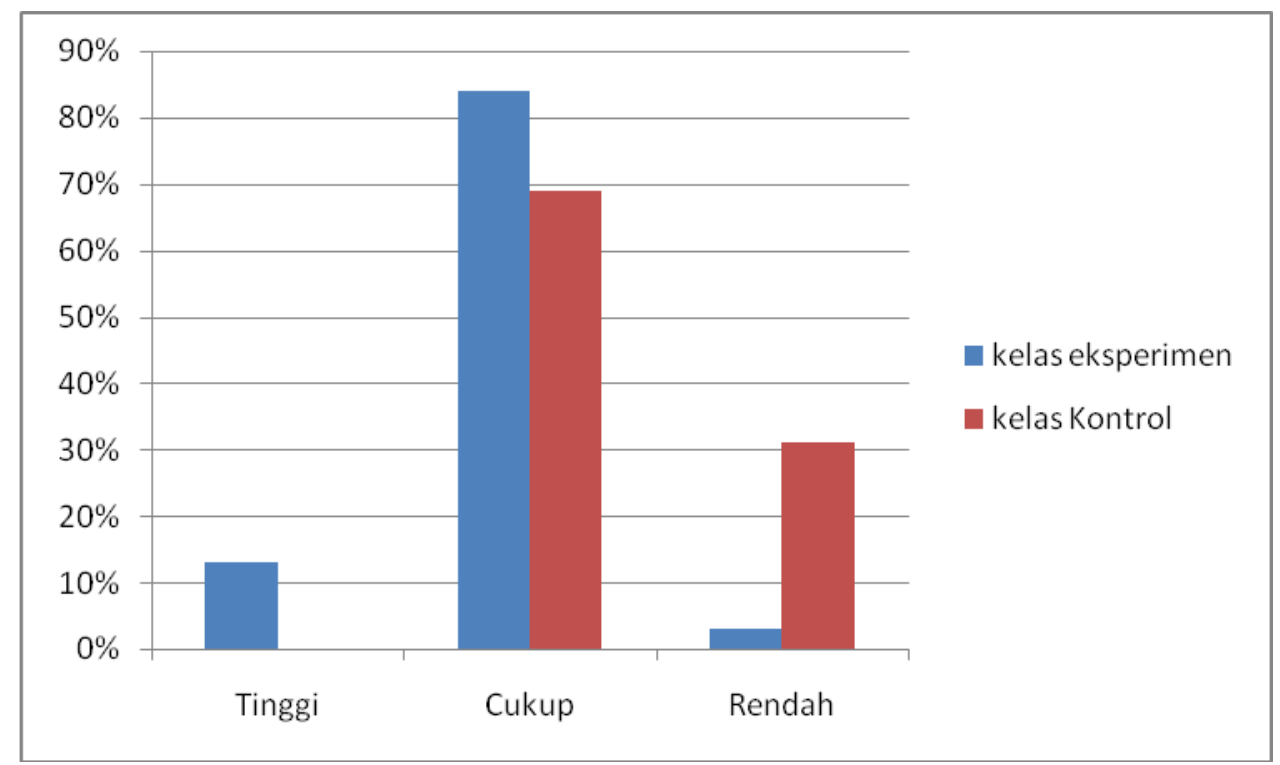

Figure 1. Number of learning outcomes by ARIAS learning model

The paired sample t-test was used to test the increase in learning outcomes of the experimental class and the control class. From the results of the paired test calculations obtained the value of sig. (2tailed) $=0.000<0.05$ which means that the increase in learning outcomes as well as in the control class there is an increase in learning outcomes by obtaining nilah sig. (2paired $=0.000<0.05$ which means that there is an increase in learning outcomes.

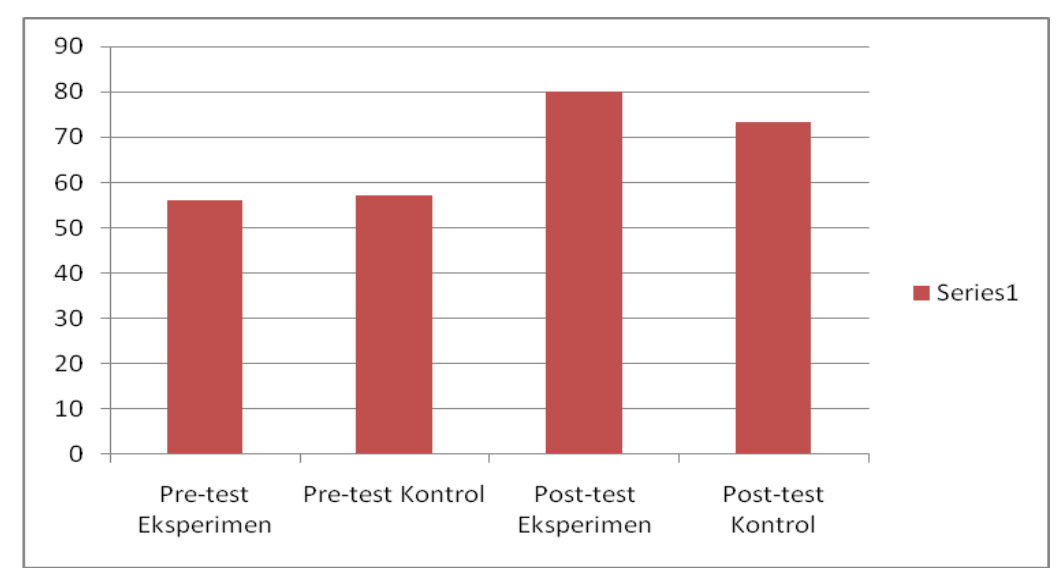

Figure 2. Number of sample test of the experimental class

Paired sample test results t-test where the average value of the experimental class before being given treatment (pre-test) amounted to 56.07 while after being given 
Indonesian Journal of Learning and Instruction Volume 2, Issue 1, April 2019
p-ISSN 2614-8250, e-ISSN 2614-5677

https://journal.uniku.ac.id/index.php/IJLI treatment (post-test) of 79.97 means that there is an increase in learning outcomes so it can be concluded also that the learning model is audiovisual aided effectively improve learning outcomes in English subject.

\section{CONCLUSION}

ARIAS Learning Model assisted by audiovisual media and conventional models assisted by audio-visual media there are differences in learning outcomes shown from the results of the average experimental group of 79.96 and the control group of 73.34 and through testing using the t-test obtained $t$ count $=3.375$ with a value sig. $(2$-tailed $)=$ $0.001<0.05$, there are significant differences between the experimental class and the control class.

ARIAS learning model assisted by audiovisual media proved to be able to effectively improve significant learning outcomes, shown from the results of paired sample t-test results obtained t count of 20.37 with sig $=0,000<0.05$. Improved learning outcomes Can be seen from the normalized gain as many as $84 \%$ of students experienced an increase which included enough categories.

\section{SUGGESTION}

It is expected that the Arias learning model can be applied in the learning process because it is proven effective in improving learning outcomes. Audiovisual media can help the learning process so that students can concentrate more and have a clear picture of the transfer of knowledge provided by the lecturer.

\section{REFERENCES}

Ahmadi, A., \& Supriyono, W. (2013). Psikologi belajar. Jakarta: Rineka Cipta.

Bolton, K. (2008). English in Asia, Asian Englishes, and the issue of proficiency. English Today, 312.

Budiman, M. A. (2017). Keefektifan bimbingan klasikal berbantuan media audio visual terhadap pernikahan usia dini. Jurnal Penelitian Pendidikan Indonesia, 1-5.
Budiman, M. A. (2018). Teknik pemilihan media bimbingan dan konseling pada guru bimbingan dan konseling sekota Tegal. Jurnal Penelitian Pendidikan Indonesia , 1-5.

Carson, C. H. (2006). The relationship between hypermedia producers' preferred learning styles and the motivational aspects of their productions. Journal of Education for Library and Information Science, 106-126.

Dimyati \& Mudjiono. (2013). Belajar dan pembelajaran. Jakarta: Rineka Cipta.

Gu, P., \& Guo, J. (2017). Digital case-based learning system in school. Plosone, 1-15.

Hidayat, M. S., \& Waseso, H. P. (2017). Penerapan kurikulum berbasis KKNI pada prodi PGMI Unsiq Jawa Tengah. Jurnal Ilmiah PGMI, 3348.

National, I., \& Macalister, J. (2010). Language curriculum design. New York: Routledge.

Pertiwi, D. L., Sudarsono, \& Arifin, Z. (2015). Internal factors of English learning achievement. Jurnal Pendidikan dan Pembelajaran, 1-12.

Qu, W. (2012). Practical English and the crisis of English studies. English Today, 15-20.

Risha, N., Tarmizi, \& Saminan. (2017). Penerapan model pembelajaran ARIAS terintegrasi. JIM, 30-35.

Sadiman, S. A., Raharjo, R., Haryono, A., \& Rahardjito. (2012). Media pendidikan, pengertian, pengembangan dan pemanfaatan. Jakarta: Rajagrafindo Persada.

Setiawan, D. (2017). Pengembangan model kurikulum berorientasi KKNI di Fakultas Ilmu Sosial Universitas Negeri Medan. Jurnal Pendidikan Ilmu-Ilmu Sosial, 112-120.

Sugiono. (2010). Metode penelitian pendidikan pendekatan kuantitatif, kualitatif. Bandung: Alfabeta.

Sugiyono. (2014). Metode penelitian dan pendidikan pendekatan kuantitatif, kualitatif dan $R \& D$. Bandung: Alfabeta.

Sulistyaningrum, D. E., Karyanto, P., \& Sunarno, W. (2015). Pengembangan model berbasis model pembelajaran ARIAS untuk memberdayakan motivasi dan berfikir kritis siswa pada materi ekosistem. Jurnal Inkuiri, 104-116.

Sutiah. (2011). The implementation of Communicative Language Teaching (CLT) within group-work in an English as Foreign Language (EFL) elementary classroom in Indonesia. International Journal of Arts \& Sciences, 205-258.

Tomlinson, B. (2012). Materials development for language learning and teaching. Language Teaching, 143-179.

Zein, M. S. (2017). Elementary English education in Indonesia: Policy developments, current 
Nur Laila Molla \& Muhammad Arif Budiman Sucipto

The effectiveness of ARIAS learning model assisted audiovisual media improving learning outcomes practices, and future prospects. English Today, $33(1), 53-59$. 